\title{
Can mesenchymal stem cell survive in hydroxyapatite sulphate?
}

\author{
Erica Kholinne, Ismail H. Dilogo, Phedy \\ Department of Orthopaedy and Traumatology, Faculty of Medicine, Universitas Indonesia / Cipto Mangunkusumo Hospital, Jakarta, Indonesia
}

\begin{abstract}
Abstrak
Latar belakang: Sel Punca Mesenkimal (SPM) berfungsi sebagai penyedia komponen osteogenik dalam penyembuhan fraktur. Pada kasus dengan defek tulang, penyembuhan juga memerlukan komponen osteokonduktif (scaffold). Kalsium hidroksiapatit sulfat (HA-CaSO4) telah digunakan secara luas sebagai bone void filler, mampu berperan sebagai scaffold untuk SPM, namun belum ada penelitian yang mengevaluasi pengaruh scaffold terhadap viabilitas SPM.

Metode: Dilakukan isolasi SPM dari sumsum tulang krista iliaka kelinci Giant Flamish dan diekspansi dalam medium DMEM rendah glukosa dengan teknik histogradient density. Setelah 1 minggu, sel di subkultur pada TC flask ukuran 25 cc sebagai pasase pertama, kemudian dilakukan pergantian medium setiap 3 hari. Ketika subkultur dikerjakan, kami membenamkan pellet HA-CaSO4 pada flask tersebut. Lalu evaluasi dilakukan pada sel tersebut dengan menggunakan mikroskop cahaya setiap minggu.
\end{abstract}

Hasil: Pada minggu pertama, SPM sangat sulit diidentifikasi karena dominasi kristal HA-CaSO4. Memasuki minggu ketiga, SPM telah tumbuh dan kristal HA-CaSO4 sudah dibilas dengan pergantian medium. Pada minggu keempat, SPM tetap terlihat pada evaluasi.

Kesimpulan: HA-CaSO4 dapat digunakan sebagai kandidat scaffold yang unggul untuk menghantarkan SPM secara in vivo tanpa mempengaruhi kelangsungan hidup SPM. (Med J Indones 2012;21:8-12)

\begin{abstract}
Background: Many studies have reported the role of Mesenchymal Stem Cells (MSC) in treating fractures. In case with bone defect, fracture healing needs not only osteogenic but also osteoconductive component (scaffold). Hydroxyapatite calcium sulphate (HA-CaSO4) being widely used as bone void filler, may serve as scaffold for MSC. However, the effect of this scaffold to the viability of MSC has not been evaluated before.

Methods: MSC were isolated from the iliac marrow of a Giant Flamish rabbit, and expanded in DMEM using histogradient density. After one week, they were sub-cultured in a $25 \mathrm{cc}$ TC flask (passage 1) and have the medium replaced every 3 days. During the subculture, we embedded a HA-CaSO4 pellet into the flask. The cells were evaluated under inverted microscope at a weekly interval.

Results: At the first week, MSC are difficult to be identified in microscope due to the large number of HA-CaSO4 crystals. By the third week however MSC have grown and the HA-CaSO4 crystals can readily be washed off by medium replacement. By the fourth weeks, MSC can be still seen on microscope.

Conclusion: HA-CaSO4 could serve as a good scaffold due to its pellet shape and easily absorbed, thus providing revascularization which is essential for bone healing.In addition, HA-CaSO4 does not interfere with MSC survival. (Med J Indones 2012;21:8-12)
\end{abstract}

Keywords: Fracture healing, Hydroxyapatite Calcium Sulphate (HA-CaSO4), Mesenchymal Stem Cells (MSC)

Mesenchymal stem cells (MSC) had been widely used in orthopaedics surgery field such as in treating bone, cartilage, tendon, and ligament problems. ${ }^{1}$ Many of these problems had successfully treated due to its potency and capability of proliferating and differentiate into osteogenic, chondrogenic, fibrogenic and myogenic lineage (Figure 1$){ }^{2}$ Fracture with bone defect as one of orthopaedic problems is considered to be a challenging and devastating problem. ${ }^{3}$ It is well known that such cases are often occurred in high energy trauma for example motor vehicle accident.

The research on fracture healing is a continuous and ongoing process. This is also supported by the advancing technique development of tissue engineering in which the diamond concept of fracture healing is applied. ${ }^{4}$ Diamond concept consists of osteoconductive matrix, osteoinductive signals, mechanical factor and osteogeneic cells which simultaneously will encourage fracture healing. ${ }^{5}$

Many studies have reported the role of MSC in treating fractures. ${ }^{6-9}$ Fracture healing is a complex and dynamic process involving both biologic and mechanic aspect. ${ }^{5}$ MSC will provide osteogeneic component driven by the proliferation and differentiation of those osteoprogenitor cells into osteogeneic lineage.,10-13 Later on it will end as osteoblast and laid its matrix and mineralized to form callus. ${ }^{14}$ 




Figure 1. The potency of mesenchymal stem cell to differentiate into many tissue, for example: bone tissue

Both osteoconductive and osteogeneic component are beneficial in treating fracture with bone defect. ${ }^{15,16}$ Osteoconductive component is represented by the scaffold. It had been reported in previous study that combination of MSC with osteoconductive component will give better result. The scaffold can be provided by the bone itself or synthetic. ${ }^{17}$ Synthetic scaffold has many variety regarding its structural components. One of those scaffolds is Hydroxyapatite calcium sulphate (HA-CaSO4). It has been used widely in orthopaedic surgery as bone void filler. However, the effect of this scaffold due to the viability of MSC has not been evaluated yet.

\section{METHODS}

Ethical clearance was obtained prior to the study. We conduct our research at the IHVCB (Institute of Human, Viral, and Cancer Biology) and histology laboratory, Medical Faculty, Universitas Indonesia from June to September 2010. At the histology laboratory a Giant Flemish rabbit was included in the study. After anesthetized with xylazine and ketamin, one cc of bone marrow was aspirated percutaneously from the iliac crest. It was then expanded by using histogradient density. First, it was diluted 1:1 with PBS (phosphate buffer saline, Gibco, Grand Island,
New York) and centrifugated at $2500 \mathrm{rpm}$ for 15 minutes at $20^{\circ} \mathrm{C}$. The buffycoat of the suspension was aspirated and resuspended with low glucose DMEM (Dulbecco's modified eagles medium, Gibso, Grand Island, New York). Incubation of the final suspension then was incubated at $37^{\circ} \mathrm{C}, \mathrm{O}_{2}$ flow of $20 \%$ and $\mathrm{CO}_{2}$ of $5 \%$. At the end of the first week, there cells consist of non-adherent and adherent cells. Those non-adherent cells were washed twice with PBS leaving the adherent cells to the $25 \mathrm{cc}$ TC flask. Fresh complete medium of the above was added and replaced every 3 days. After one week, those cells were sub-cultured in a 25 cc TC flask (passage 1). During the subculture, we embedded a HA-CaSO4 pellet into the flask. The cells were evaluated under inverted microscope at a weekly interval. The serial evaluation then was performed at the first, third and fourth week (Figure 2). There is no pellet replacement during the evaluation.

\section{RESULTS}

Evaluation was performed under light microscope at 100 and $200 \mathrm{x}$ magnification. At the first week evaluation, the cells were difficult to be identified due to the present of large number HA-CaSO4 crystal (Figure 3). It masked the adherent cells on the bottom of TC flask. At the third week evaluation, the cells could be seen at it had been changed into fibroblast-like 

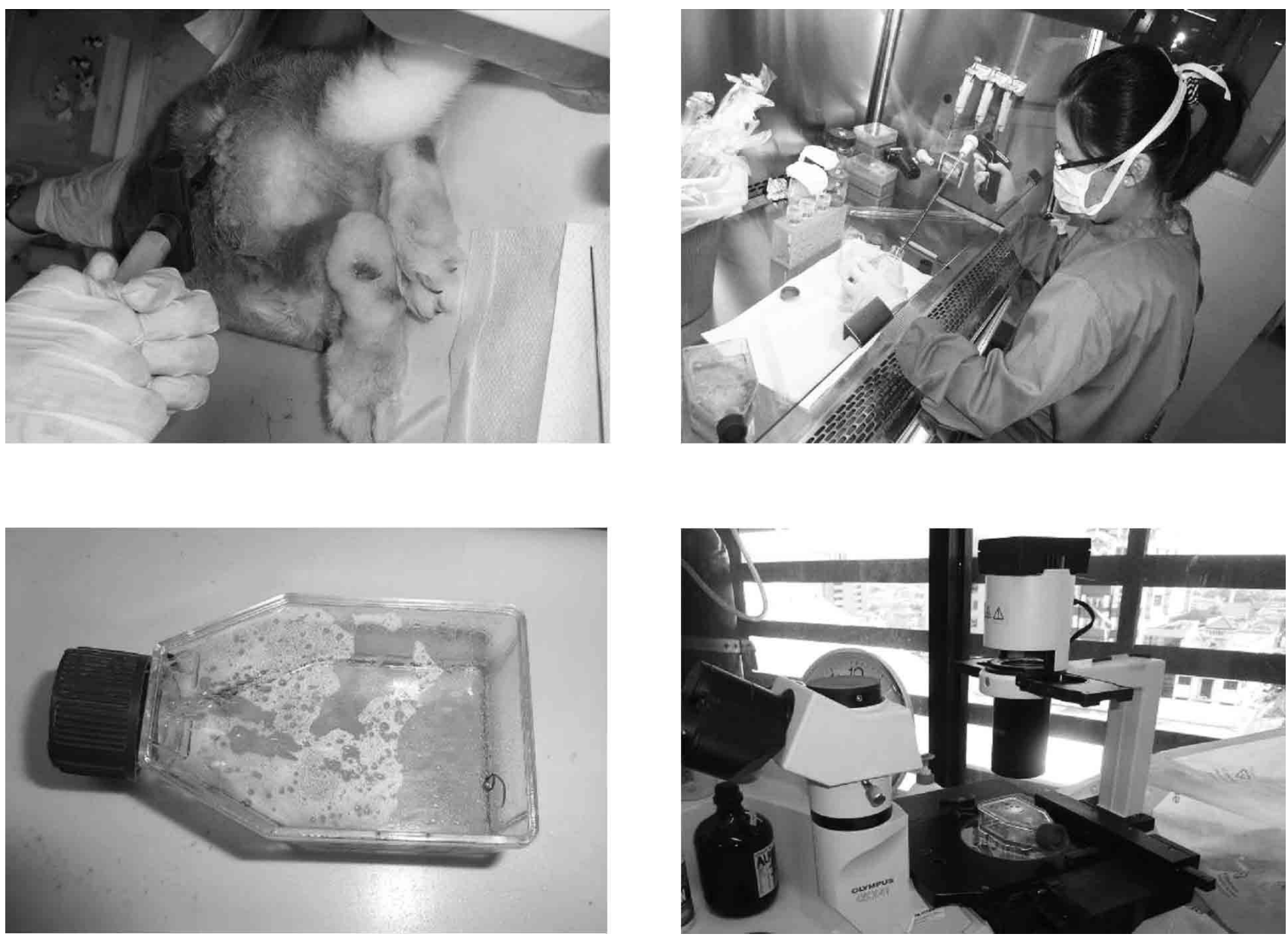

Figure 2. Methods; TOP LEFT. Aspiration of bone marrow in iliac crest, TOP RIGHT. MSC preparation in the biosafety cabinet, BOTTOM LEFT. MSC suspension in 25 cc-TC flask, BOTTOM RIGHT. MSC evaluation under inverted microscope



Figure 3. First week microscope evaluation. On 100x magnification MSC are hardly seen on microscope. There are large amount of HA-CaSO4 crystal

form or so called the MSC (Figure 4). Those cells are adherent to the TC flask that not washed by the medium replacement. The crystals of HA-CaSO4 have partially washed by the medium replacement. At the fourth week of evaluation, the MSC was still seen on the TC flask that later on confirmed its viability (Figure 5).

\section{DISCUSSION}

HA-CaSO4 is an analogous mineral component of bones being chosen for this research for its widely known usage as a biomaterial in orthopaedics surgery. ${ }^{18}$ HA-CaSO4 as a synthetic scaffold will serve as a 



Figure 4. Third week microscope evaluation. On 100x magnification, MSC have grown, HA-CaSO4 are readily be washed off by medium replacement.


Figure 5. Fourth week microscope evaluation. On 100x magnification, MSC still seen on microscope.

good scaffold due to its pellet shape if compared to other structure. The porosity of this scaffold had some advantages such as increasing the total surface contact area due to its osteoconductive component. Porosity is also known to influence the biological performance of calcium hydroxyapatite by providing framework for bone growth into the pore, which then becomes vascularized easily, especially in soft callus stage. HA$\mathrm{CaSO} 4$ structures then create surface roughness that enhances attachment, proliferation and differentiation of the mesenchymal stem cell. The access of penetrating MSC to the scaffold is another important advantage for those cells to survive. ${ }^{19}$

A research conducted by Jagdale et al. had similar purposes in investigating the in vitro biocompatibility on cell adhesion of sheep bone marrow derived mesenchymal stem cell. They found that HA-CaSO4 has good biocompatibility and in addition it can stimulate cell adhesion to this biomaterial. However, the evaluation only been done one time that is at the end of the first week. This seems not representable due to the viability not only essential in the first week but it is important for the process until the osteoid was laid from the osteoblast which occurred in the third week. Due to this reason, we conduct the evaluation until the third week. ${ }^{19}$

A study by Fennema et al. also shown that bone marrow volume during aspiration is at least $8 \mathrm{~mL}$ in order to reduce the risk of lower cell numbers. However, this study only conducted in human subject. In animal 
models there is no study yet regarding the minimal aspiration volume of bone marrow collection. In our study, only $1 \mathrm{~mL}$ bone marrow was aspirated..$^{20}$

We did not investigated the surface antigen expression as a proof of MSC existent but their adherence to the bottom of TC flask is considered the indication of stem cells. ${ }^{4}$ The morphology of the cell which is fibroblastlike cell is supported to be recognized as mesenchymal stem cells. Further study should be done regarding the characterization to confirm those cells objectively.

Another shape of HA-CaSO4 is granule which is also widely used in orthopaedics fields. Further investigation about the viability of those cells in granule structure of HA-CaSO4 is also important. The porosity and surface roughness of the structure might affect the adherence of those cells to it. ${ }^{18}$

In conclusion, scaffold structure is essential to the viability of MSC. Without a reliable structure there is no chance that MSC could play it roles in enhancing fracture healing. HA-CaSO4 is hoped to be an excellent scaffold candidate to deliver MSC in vivo. Further investigation regarding the expansion and differentiation on this scaffold will be an important issue.

\section{Acknowledgments}

The authors would like to acknowledge the Directorate Research and Public Service (DRPM) Universitas Indonesia and Research Manager of Faculty of Medicine, Universitas Indonesia for providing the research fund, The Histology Department of Faculty of Medicine from Universitas Indonesia for providing the animal lab and technical assistance, and the Institute of Human Virology and Cancer Biology of Universitas Indonesia (IHVCB-UI) for the laboratory work and assistance.

\section{REFERENCES}

1. Arizeh TL, Peter SJ, Archambault MP, van den Bos C, Gordon S, Kraus K, et al. Allogeneic mesenchymal stem cells regenerate bone in a critical-sized canine segmental defect. J Bone Joint Surg Am. 2003;85-A:1827-35.

2. Muschler GF, Nakamoto C, Griffith LG. Engineering principles of clinical cell-based tissue engineering. J Bone Joint Surg Am. 2004;86-A:841-58.
3. DeCoster TA, Gehlert RJ, Mikola EA, Pirela-Cruz MA. Management of posttraumatic segmental bone defects. J Am Acad Orthop Surg. 2004;12:28-38.

4. McGonagle D, English A, Jones EA, The relevance of mesenchymal stem cells in vivo for future orthopaedic strategies aimed at fracture repair. Curr Orthopaed. 2007;21:262-7.

5. Yoo JU, Johnstone B. The role of osteochondral progenitor cells in fracture repair. Clin Orthop. 1998;355S:S73-81

6. Novicoff WM, Manaswi A, Hogan MV. Critical analysis of the evidence for current technologies in bone-healing and repair. J Bone Joint Surg Am. 2008;80 Suppl 1:85-91.

7. Kraus KH, Kadiyala S, Wotton H, Kurth A, Shea M, Hannan M, et al. Critically sized osteo-periosteal femoral defects: a dog model. J Invest Surg. 1999;12:115-24.

8. Termaat MF, Den Boer FC, Bakker FC. Bone morphogenetic proteins: development and clinical efficacy in the treatment of fractures and bone defects. J Bone Joint Surg Br. 2005;87:1367-78.

9. Vögelin E, Jones NF, Huang JI. Healing of a critical-sized defect in the rat femur with use of a vascularized periosteal flap, a biodegradable matrix, and bone morphogenetic protein. J Bone Joint Surg Br. 2005;87:1323-31.

10. Vats A, Tolley NS, Buttery LDK, Polak JM. The stem cell in orthopaedic surgery. J Bone Joint Surg Br. 2004;86B:159-64.

11. Rust PA, Kalsi P, Briggs TW. Will mesenchymal stem cells differentiate into osteoblasts on allograft? Clin Orthop Rel Res. 2006; 457:220-6.

12. Serakinci N, Keith WN. Therapeutic potential of adult stem cells. Eur J Cancer. 2006;42:1243-6.

13. Bruder SP, Jaiswal N, Ricalton NS, Mosca JD, Kraus KH, Kayidala S. Mesenchymal stem cells in osteobiology and apllied bone regeneration. Clin Orthop. 1888;355S:S24756.

14. SalterRB,editor.Fractures and jointinjuries-general features. Textbook of disorders and injuries of the musculoskeletal system, 3rd ed. Maryland: William\&Wilkins; 1999. p. 41797.

15. Finkemeier CG. Bone-grafting and bone-graft substitutes. J Bone Joint Surg Br. 2002;84:454-64.

16. De Long WG, Einhorn TA, Koval K. Bone grafts and bone graft substitutes in orthopaedic trauma surgery. J Bone Joint Surg Br. 2007;89:649-58.

17. Greenwald AS, Boden SD, Goldberg VM. Bone-graft substitutes: facts, fictions, and applications. J Bone Joint Surg Br. 2001;83:S98-103.

18. Mour M, Das D, Winkler T, Hoenig E, Mielke G, Morlock MM. Advances in porous biomaterials for dental and orthopaedic applications. Materials. 2010;3:2947-74.

19. Jagdale PN, Bamane SR. Calcium hidroxyapatite bioceramics and evaluation of their in vitro biocompatibility. Research Journal of Pharmaceutical, Biological and Chemical Sciences. 2011;2(1):180-6.

20. Fennema E, Rennard AJS, Leusink A, van Blitterswijk CA, De Boer J. The effect of quality of bone marrow aspiration strategy on the yield and quality of human mesenchymal stem cells. Acta Orthop. 2009;80:618-21. 